\title{
MATEMATIKA A TANTÁRGY-PEDAGÓGIAI KUTATÁSI PROGRAMBAN: EGY „KRITIKUS BARÁT” GONDOLATAI
}

\section{THE CONTENT PEDAGOGY RESEARCH PROGRAM IN MATHEMATICS: REFLECTIONS OF A 'CRITICAL FRIEND'*}

\author{
Michèle Artigue \\ a matematikaoktatás professor emeritusa, Laboratoire de Didactique André Revuz, Université de Paris, Párizs, Franciaország \\ michele.artigue@univ-paris-diderot.fr
}

\begin{abstract}
ÖSSZEFOGLALÁS
A Magyar Tudományos Akadémia kezdeményezése egyedülálló lehetőséget nyújtott a magyar matematikatanítási kutatóknak, a velük együttműködő tanítóknak és tanároknak. A Tantárgy-pedagógiai Kutatási Program matematikai komponense két projekt körül szerveződött. A Korszerű Komplex Matematikaoktatás elnevezésű kutatócsoport projektje a "Varga Tamás matematikai és tanítási hagyományán alapuló koncepció" kidolgozását tǔzte ki céljául. A második csoport a Pósa Lajos által kifejlesztett felfedeztető matematikatanulás módszerére koncentrál. A programmal létrejött kapcsolatom módszertani kultúrám gazdagodásában is unikális lehetőségnek bizonyult.
\end{abstract}

\section{ABSTRACT}

The initiative of the Hungarian Academy of Sciences represented a unique opportunity for Hungarian mathematics education researchers and the teachers and teacher educators with whom they were collaborating. The mathematical component of the Content Pedagogy Research Program is organized around two projects. The primary goal of the first research group, entitled Complex Mathematics Education in the $21^{\text {st }}$ Century, is 'to develop a concept, founded on the tradition for mathematics and teaching methodology of Tamás Varga". The second group focuses on the method for Discovery Learning in Mathematics developed by Lajos Pósa. Being associated with this program was also a unique opportunity for me to enrich my didactic culture.

Kulcsszavak: tantárgy-pedagógia, komplex matematika, felfedeztető tanulás, magyar matematikai hagyományok

Keywords: content pedagogy, complex mathematics, discovery learning, Hungarian mathematical traditions

*Az angol nyelvü cikk letölthető a folyóirat online változatában. 
2016-ban a Magyar Tudományos Akadémia arra kért fel, hogy „kritikus barátként" kísérjem figyelemmel az általa akkor indított Tantárgy-pedagógiai Kutatási Program matematikai komponensét. A felkérést habozás nélkül elfogadtam. Gosztonyi Katalin éppen ekkor védte meg PhD-értekezését a Szegedi Tudományegyetem Bolyai Intézete és intézetem, az Université Paris-Diderot LDAR kutatólaboratóriuma közös témavezetésével (co-tutelle). Doktori tanulmányi évei alatt sok megbeszélést folytattunk. Hála e diszkusszióknak, világossá vált számomra az „új matematika” (New Math) korszakában Varga Tamás meghatározó szerepe a magyar tantervi refommunkálatokban. Megismertem Varga elmélyült és eredeti gondolatait a matematika oktatásáról, és az őt inspiráló magyar matematikai és matematikatanítási hagyományt. Nem hiszem, hogy kivételes eset lennék. Bár Pólya György és Lakatos Imre távlatos írásai évtizedek óta nemzetközi érdeklődést váltanak ki, ezt a tradíciót a legtöbb matematikatanítást kutató csak felületesen ismeri.

Hiányoznak azok a széles körben hozzáférhető közlemények, amelyek rendszeres leírással kínálnak lehetőséget e hagyomány megismerésére, segítenek azt elhelyezni a matematika oktatásának mai térképén. Hiányoznak a Varga-módszer lehetőségeit és korlátait pontosító tudományos tanulmányok, amelyekböl megérthető létrejöttének és fejlődésének dinamikája az oktatásnak a globalizációs nyomás alatt gyorsan változó világában. Más hagyományokkal összevetve (lásd például az európai didaktikai hagyományok összehasonlító leírását az ICME-13 tematikus előadási délutánja alapján [Werner et al., 2019]) Varga módszertani koncepciójának kidolgozása és elméleti megalapozása kevésbé haladt előre.

Az MTA kezdeményezése felismerte ezeket az igényeket, és jelentős eszközöket adott a szükséges vizsgálatok elvégzésére. Egyedülálló esélyt adott a magyar matematikatanítás-kutatók és a velük együttmüködő matematikatanárok számára. A programhoz csatlakozás számomra is értékes lehetőséget nyújtott didaktikai kultúrám gazdagítására, ezért megtisztelőnek éreztem az MTA, különösképpen annak elnöke, Lovász László professzor bizalmát, akinek megismerhettem az oktatási kérdések iránti érdeklődését, amikor ő volt az IMU (International Mathematical Union) elnöke, jómagam pedig az ICMI (International Commission on Mathematical Instruction) elnökeként tevékenykedtem.

A Tantárgy-pedagógiai Kutatási Program matematikai komponense két projekt köré szerveződött. A Komplex matematikatanítás a 21. században címü projektet Vancsó Ödön vezeti, és amint honlapjuk bemutatkozó szövege megfogalmazza, elsődleges céljuk ,a Varga Tamás módszertanán és matematikai tradícióján alapuló olyan matematikatanítási koncepció kidolgozása, amely az elmúlt évtizedek tudományos fejlődését és technikai kihívásait figyelembe veszi”. A tervezet célul tủzi ki az eredetileg általános iskolások számára megfogalmazott Varga-módszer kiterjesztését a középiskolákra is. A másik kutatási programot az MTA-Rényi Felfedeztetö Matematikatanitás Kutatócsoport valósítja meg Juhász Péter 
vezetésével, akik a Pósa Lajos által kidolgozott felfedeztető matematikatanulás módszerére koncentrálják munkájukat. Fő céljuk a módszer elméleti megalapozása, beillesztése az aktuális nemzetközi kutatási irányzatokba és a köztük folyó szakmai párbeszédbe. Vizsgálni kívánják a módszer alkalmazhatóságát a tehetséges diákok nem formális (órarenden kívüli) tanításánál szélesebb körben. A két projekt közös célja a magyar matematikaoktatási hagyomány nemzetközi láthatóságának javítása és az e hagyomány értékei köré szerveződő kutatói közösség kialakítása.

Az elmúlt három évben e kutatásokat kísértem figyelemmel. Budapesti látogatásaim során személyesen is megismerkedhettem a kutatásban részt vevőkkel, doktorhallgatóikkal és a kutatókkal együtt dolgozó tanárokkal. Részt vettem előadóüléseken és konferenciákon, meglátogattam tantermi órákat, továbbá a Pósa Lajos módszerét követő órarendi és iskolán kívüli foglalkozásokat. Nemzetközi konferenciákon, valamint Gosztonyi Katalin számos franciaországi látogatása során is módom volt diszkusszióink folytatására. Szélesebb képet alkothattam az MTA támogatta programról a szegedi Bolyai Intézetben 2018-ban tett látogatásom során. Végül, szoros kapcsolatban voltam a VARGA 100 konferencia szervezőivel, amit 2019 novemberében Varga Tamás születésének centenáriumi évfordulója alkalmából tartottak Budapesten, amelyen természetesen részt is vettem.

Nehéz néhány sorban összegeznem mindazt, amit a három év alatt tanultam. Mindkét csoport számos erősséggel bír, és kezdetektől nagy hatással volt rám a kutatók és tanárok szoros együttmüködése, a projektek mellett elkötelezett tanárok nagy száma és motiváltsága. Komoly hatást tett rám mindazok matematikai kultúrája, akikkel kapcsolatba kerültem. A kihívás azonban igen jelentős volt. Az első kutatócsoport a kezdetektől több, egymással kapcsolatot tartó, ám önálló kutatási tervet követő részcsoportból szerveződött; összehangolásuk, különféle aktivitásaik közös célt szolgáló hasznosítása igazi kihívást jelentett. A második programot végrehajtó csoport nagyon erős gyakorlati tevékenységre volt képes, de céljai megvalósításához jelentős ugrásra volt szükség a tanítási gyakorlattól az akadémiai kutatás elvárásaihoz. Varga oktatási víziójának és módszertanának a kognitív és didaktikai ismeretek, valamint az oktatástechnikai eszközök fejlődését figyelembe vevő koncepcionális fejlesztése, valamint annak beillesztése a korszerü elméletalkotásba és diskurzusba nagyon ambiciózus célkitüzésnek bizonyult. Ennek a célkitüzésnek megvalósításához Gosztonyi Katalin doktori dolgozata csak az első építőkő volt. Hasonló kihívással találkozik a második kutatócsoport is a Pósa-módszer elméletének kidolgozásában, de ez a projekt egy másik igen komoly kihívást is vállal: szeretnék kitalálni és megvizsgálni ennek a matematikai tehetség felkutatására és táplálására megalkotott, a nem formális tanítás körülményei között alkalmazott módszernek más körülmények közötti „gazdaságosságát”, például a tanórai oktatásban, illetve a hátrányos helyzetü diákok között. A feladat fontosságát megerösítette a VARGA 100 konferencia 
panelvitája, amely megállapította, hogy a Pósa-módszernek és más kutatásalapú tanítási formáknak (Inquiry Based Education) alkalmazását nem szabad egy szűk elitre korlátozni, a minőségi matematikatanításhoz mindenkinek hozzá kell férnie (UNESCO, 2011).

Az elmúlt három évben felmérhettem a kutatások előrehaladására - gyakran igen erős korlátok között - fordított erőfeszítést és energiaráfordítást. Mérhető ismérveit láttam a koncepciók kimunkálásában elért haladásnak, amely az empirikus munkával és a tanárszakértők gyakorlati elemzéseivel összhangban folyt. Jó példaként említem a „feladatszálak” vagy a „feladatsorok” témakörében mindkét csoport által végzett kutatást, a kapcsolatteremtést a didaktika antropológiai elméletével (Antropological Theory of Didactics, ATD), továbbá a feladatváltozatok kínai módszerével. Utóbbi témákban az ICME-14 konferenciára közös diszkuszsziócsoportot szerveznek kínai, francia és olasz kutatókkal. Mély benyomást tett rám a Repülő Iskola Program sikere, illetve a kutatási eredmények gyors bejuttatása a tanárképzésbe. Megfigyelhettem azokat az erőfeszítéseket, amelyekkel kapcsolatokat építettek például az MCG (a matematikai kreativitás és tehetség fejlesztésének nemzetközi csoportja, International Group of Mathematical Creativity and Giftedness) közösségéhez, erősítették korábbi együttmüködéseiket Németország, Finnország, az USA és országom kutatóival. Új együttmüködéseket kezdeményeztek, nagyban megnőtt a fontos nemzetközi konferenciákra, például a CERME- (European Society for Research in Mathematics Education) konferenciákra beküldött publikációik száma. Sikerült elnyerniük a 2023. évi CERME-konferencia megrendezésének jogát. Értékelem a publikációk közzétételére tett erőfeszítéseket (lásd például Gosztonyi et al., 2018; Gordon Győri-Juhász, 2018), bár ezek még nem hozták meg a teljes elvárt eredményt. ${ }^{1}$ Végül igen bátorító jelnek tekintem a kutatói közösség növekedését és szellemi beérését, különösképpen a doktorhallgatók növekvő számát, bár a témavezetői potenciál még korlátozott.

Az előrehaladást mindazok értékelhették, akik részt vettek a ragyogó sikerü VARGA 100 konferencián. Meghallgatva a magyar kutatók és doktorhallgatók prezentációit, látva a diszkussziók magas színvonalát, az általuk szervezett mühelyeket és az irántuk megnyilvánuló érdeklődést, megismerve a külföldi résztvevők rendkívül pozitív értékelését a konferencia egészéről, azt gondolom, hogy magyar kollégáim büszkék lehetnek az elvégzett munkára, és megnövekedett önbizalommal törekedhetnek célkitủzéseik teljes megvalósítására. A Sanghajban 2021-ben rendezendő ICME-14 konferenciára elfogadott nemzeti prezentáció javaslatuk kiváló lehetőség lesz arra, hogy munkájukat és annak eredményeit meg-

\footnotetext{
${ }^{1}$ A TMCS (Teaching Mathematics and Computer Science) különszámában, amelyet a VARGA 100 konferencia anyagából válogattak a bírálók, a két csoport tíz közleménye jelenik majd meg, ami jelentősen hozzájárul e cél megvalósításához.
} 
ismertessék a nemzetközi kutatói közösséggel. Személyesen készen állok, hogy tovább kísérjem előrehaladásukat, amennyiben ezt ők is így kívánják. Felhasználom e cikk kínálta alkalmat, hogy nyilvánosan megköszönjem a meleg fogadtatást és a tanulásra kapott lehetöséget.

\section{IRODALOM}

Gordon Győri J. - Juhász P. (2018): An Extra-curricular Gifted Support Programme in Hungary for Exceptional Students in Mathematics. In: Taber, K. S. - Sumida, M. - McClure, L. (eds.): Teaching Gifted Learners in STEM Subjects: Developing Talent is Science, Technology, Engineering and Mathematics. New York, NY: Routledge, 89-106. http://real.mtak.hu/67157/

Gosztonyi K. - Vancsó Ödön - Pintér K. - Kosztolányi J. - Varga E. (2018): Varga’s "Complex Mathematics Education" Reform: At the Crossroad of the New Math and Hungarian Traditions. In: Shimizu, Y. - Vithal, R. (eds.): ICMI Study 24: School Mathematics Curriculum Reforms: Challenges, Changes and Opportunities. Conference Proceedings. 133-140. https:// www.mathunion.org/fileadmin/ICMI/ICMI\%20studies/ICMI\%20Study\%2024/ICMI\%20 Study\%2024\%20Proceedings.pdf

UNESCO (2011): Challenges in Basic Mathematics Education. Paris: UNESCO, https://unesdoc. unesco.org/ark:/48223/pf0000191776_eng

Werner, B. - Artigue, M. - Mariotti, M. A. et al. (eds.) (2019): European Traditions in Didactics of Mathematics. New York: Springer Open 